\title{
Perbandingan Kadar Interleukin-17 Serum Pasien Akne Vulgaris Tipe Papulopustular dengan Komedonal
}

\author{
Shinta Maulinda, ${ }^{1}$ Reti Hindritiani, ${ }^{2}$ Kartika Ruchiatan, ${ }^{2}$ Oki Suwarsa ${ }^{2}$ \\ ${ }^{1}$ RSUD Kab. Subang, ${ }^{2}$ Departemen Ilmu Kesehatan Kulit dan Kelamin Fakultas Kedokteran Universitas \\ Padjadjaran/Rumah Sakit Dr. Hasan Sadikin Bandung
}

\begin{abstract}
Abstrak
Patogenesis akne vulgaris (AV) bersifat multifaktorial dan faktor yang berperan penting adalah inflamasi yang terutama diinduksi oleh reaksi imunologis terhadap Propionibacterium acnes ( $P$. acnes). Bakteri ini dapat ditemukan baik pada lesi inflamasi berupa papula dan pustula, maupun noninflamasi seperti komedo, dengan jumlah P. acnes lebih tinggi pada lesi inflamasi. Secara klinis komedo merupakan lesi noninflamasi, namun secara mikroskopis sudah terjadi inflamasi. $P$. acnes dapat menginduksi pelepasan sitokin proinflamasi antara lain IL17. Tujuan penelitian ini adalah membandingkan kadar IL-17 serum antara pasien AV tipe papulopustular dan komedonal. Penelitian ini merupakan penelitian analitik observasional secara potong lintang dengan peserta penelitian masing-masing 12 pasien AV tipe papulopustular dan komedonal derajat dua atau lebih di Poliklinik Dermatologi Kosmetik Departemen Ilmu Kesehatan Kulit dan Kelamin Rumah Sakit Dr. Hasan Sadikin Bandung selama periode Oktober-November 2014. Pada kedua kelompok dilakukan pengambilan darah tepi untuk pengukuran kadar IL-17 serum dengan metode ELISA. Hasil penelitian menunjukkan kadar IL-17 serum rata-rata (SD) pada pasien AV tipe papulopustular adalah 0,65 $(1,12) \mathrm{pg} / \mathrm{mL}$, sedangkan pada tipe komedonal adalah 0,46 $(0,42) \mathrm{pg} / \mathrm{mL}$, perbedaan tersebut secara statistik tidak bermakna $(\mathrm{p}=1,000)$. Simpulan, kadar IL-17 serum pasien AV tipe papulopustular tidak berbeda dibanding dengan AV tipe komedonal menunjukkan bahwa kemungkinan pada lesi komedo sudah terjadi inflamasi. [MKB. 2016;48(3):160-3]
\end{abstract}

Kata kunci: Akne vulgaris, IL-17 serum, tipe komedonal, tipe papulopustular

\section{Comparison of Interleukin-17 Serum Level between Papulopustular and Comedonal Types of Acne Vulgaris}

\begin{abstract}
The pathogenesis of acne vulgaris (AV) is multifactorial and inflammation, which is primarily cause by induction of immunological response to Propionibacterium acnes (P. acnes), is suggested as the main important factor in AV development. These bacteria can be found in the form of papules and pustules in inflammatory lesions and as comedones in noninflammatory lesions, with a higher presentation seen in the inflammatory lesions. Clinically, comedo is a noninflammatory lesion; however, inflammation can be observed microscopically. P. acnes can release proinflammatory cytokines, including IL-17. The aim of this study was to compare the IL-17 serum level between papulopustular type and comedonal type of AV. This study was a cross sectional-analytic observational, conducted at the Cosmetic Dermatology Clinic, Dermatology and Venereology, Dr. Hasan Sadikin General Hospital Bandung during October-November 2014. The participants were AV patients with at least second degree papulopustular (n12) and comedonal types (n12). Blood samples from all subjects were collected and the IL-17 serum levels were measured using ELISA methods. This study showed that the mean (single deviation) IL-17 serum levels in papulopustular and comedonal type of $A V$ were $0.65(1.12) \mathrm{pg} / \mathrm{mL}$ and $0.46(0.42) \mathrm{pg} / \mathrm{mL}$, respectively, and the difference was not statistically significant (p:1.000). The IL-17 serum level in the papulopustular type is not different from that of the comedonal type of $\mathrm{AV}$ in this study, which indicates that the inflammatory events probably had occurred in comedonal lesions. [MKB. 2016;48(3):160-3]
\end{abstract}

Key words: Acne vulgaris, comedonal type, IL-17 serum level, papulopustular type

Korespondensi: Shinta Maulinda, dr., Rumah Sakit Umum Daerah (RSUD)Kabupaten Subang, Jalan Brigjen Katamso No. 37, Kabupaten Subang, Jawa Barat, mobile 08122350746, e-mail de_shin@yahoo.com 


\section{Pendahuluan}

Akne vulgaris (AV) adalah penyakit inflamasi kronik pada unit pilosebasea, ${ }^{1-3}$ yang ditandai dengan berbagai gambaran klinis lesi kulit pada wajah, leher, batang tubuh bagian atas, dan lengan atas. ${ }^{1,4}$ Lesi AV dapat dibagi menjadi lesi noninflamasi berupa komedo, serta lesi inflamasi berupa papula, pustula, dan nodul. ${ }^{3} \mathrm{AV}$ dapat mengenai semua usia, tetapi sekitar $85 \%$ kasus mengenai dewasa muda ${ }^{1,2}$ dengan rentang usia 12-24 tahun. ${ }^{5}$

Patogenesis AV itu bersifat multifaktorial, namun terdapat empat faktor utama yang berperan penting dalam patogenesis AV, yaitu peningkatan produksi sebum, ${ }^{2,3,5}$ hiperproliferasi folikel epidermal, ${ }^{3}$ kolonisasi Propionibacterium acnes (P. acnes), ${ }^{2}$ dan inflamasi., ${ }^{3,5}$ Inflamasi merupakan salah satu faktor penting yang berperan dalam patogenesis AV. Inflamasi yang terjadi pada $\mathrm{AV}$ terutama diinduksi oleh reaksi imunologis terhadap P. acnes. ${ }^{3}$

Proses inflamasi sering kali disebut sebagai proses sekunder yang terjadi pada AV. Lesi inflamasi berupa papula dan pustula, berasal dari lesi yang secara klinis disebut sebagai lesi noninflamasi, yaitu komedo terbuka dan tertutup. ${ }^{6}$ Meskipun secara klinis komedo itu merupakan lesi noninflamasi, tetapi sebenarnya pada lesi komedo telah terjadi inflamasi secara mikroskopik, dibuktikan dengan ditemukannya sitokin proinflamasi IL-1 $\alpha$ pada lesi komedo. ${ }^{7}$

Interleukin-17A atau yang sering disebut pula sebagai IL- $17^{8}$ merupakan sitokin proinflamasi yang poten, ${ }^{9}$ diproduksi oleh sel T helper (Th)17 yaitu merupakan subset dari sel T CD4+. ${ }^{+} \mathrm{IL}-17$, berperan penting dalam pembentukan penyakit inflamasi, ${ }^{10}$ yaitu antara lain psoriasis, artritis reumatoid, penyakit Crohn, penyakit obstruksi saluran napas, sklerosis sistemik, ${ }^{9}$ penyakit kulit infeksi seperti Staphylococcus, ${ }^{11}$ serta penyakit kulit inflamasi seperti dermatitis kontak alergi dan atopik. Pada AV, sekresi IL-17 dari sel Th17 didapatkan melalui diferensiasi sel $\mathrm{T} \mathrm{CD}^{+}$ dengan bantuan ketiga sitokin yang diinduksi oleh $P$. acnes, yaitu IL-1 $\beta$, IL-6, dan TGF- $\beta .^{12}$

Pada biopsi kulit lesi inflamasi pasien AV didapatkan IL-17, namun tidak pada kulit donor orang normal. ${ }^{11}$ Pada serum pasien AV dengan lesi inflamasi didapatkan peningkatan kadar IL17 , TNF- $\alpha$, IL-4, dan interferon (IFN)- $\gamma$ dibanding dengan orang normal. ${ }^{12}$ Penelitian ini bertujuan membandingkan apakah ada perbedaan kadar IL-17 di dalam serum antara pasien AV tipe papulopustular dan AV tipe komedonal.

\section{Metode}

Penelitian ini adalah penelitian klinis analitik observasional secara potong lintang dengan peserta penelitian terdiri atas dua kelompok, yaitu kelompok pasien AV tipe papulopustular dan komedonal berjumlah 12 orang masingmasing. Penelitian ini dilakukan di Poliklinik Dermatologi Kosmetik Departemen/SMF IKKK RSUP Dr. Hasan Sadikin Bandung (RSHS) selama bulan Oktober sampai November 2014 dan telah mendapatkan persetujuan etik dari Komite Etik RSHS.

Kriteria inklusi, yaitu pasien AV dengan usia lebih dari 14 tahun yang diklasifikasikan menjadi AV tipe papulopustular dan komedonal derajat dua atau lebih berdasarkan kriteria Plewig dan Kligman. Kriteria eksklusi adalah pasien AV yang mendapatkan pengobatan antibiotik seperti tetrasiklin, klindamisin, minosiklin, doksisiklin, dan eritromisin serta anti-inflamasi (steroid) dalam empat minggu terakhir berdasarkan atas anamnesis, serta pasien $\mathrm{AV}$ yang menderita penyakit kulit inflamasi lain seperti psoriasis, Morbus Hansen, dermatitis atopik dan kontak alergik, serta penyakit sistemik seperti diabetes melitus (DM), asma, tuberkulosis paru, lupus eritematosus sistemik berdasarkan anamnesis dan pemeriksaan fisis.

Bahan pemeriksaan adalah serum peserta kelompok AV tipe papulopustular dan juga komedonal, kemudian dilakukan pemeriksaan kadar IL-17 menggunakan kit high sensitivity (HS) human IL-17A (eBioscience ${ }^{\circledR}$, Vienna, Austria) menggunakan metode sandwich ELISA. Analisis statistik untuk membandingkan kadar IL-17 serum antara pasien AV papulopustular dan pasien AV komedonal menggunakan uji Mann-Whitney karena data tidak terdistribusi normal. Secara statistik perbedaan bermakna bila nilai $\mathrm{p}<0,05$.

\section{Hasil}

Peserta penelitian dibagi menjadi 2 kelompok, yaitu AV tipe papulopustular dan tipe komedonal berjumlah 12 orang masing-masing. Karakteristik peserta penelitian sebagian besar laki-laki dengan usia terbanyak 20-24 tahun. (Tabel 1).

Hasil pemeriksaan kadar IL-17 dalam serum pasien AV tipe papulopustular dan komedonal dapat dilihat pada Tabel 2. Berdasarkan uji normalitas menggunakan Kolmogorov-Smirnov, 
Shinta Maulinda: Perbandingan Kadar Interleukin-17 Serum Pasien Akne Vulgaris Tipe Papulopustular dengan Komedonal

Tabel 1 Karakteristik Pasien Akne Vulgaris dengan Tipe Papulopustular dan Komedonal

\begin{tabular}{|c|c|c|c|}
\hline \multirow{2}{*}{ Karakteristik } & AV tipe Papulopustular & AV tipe Komedonal & \multirow{2}{*}{ Total } \\
\hline & $(n=12)$ & $(n=12)$ & \\
\hline \multicolumn{4}{|l|}{ Jenis kelamin } \\
\hline Laki-laki & 10 & 6( & 16 \\
\hline Perempuan & 2 & 6 & 8 \\
\hline \multicolumn{4}{|l|}{ Usia (tahun) } \\
\hline $15-19$ & 3 & 5 & 8 \\
\hline $20-24$ & 5 & 4 & 9 \\
\hline $25-29$ & 3 & 1 & 4 \\
\hline $30-34$ & 1 & 2 & 3 \\
\hline
\end{tabular}

Keterangan: * berdasarkan uji Fisher-Exact dan ** berdasarkan uji chi-square; Kelompok I: AV papulopustular, Kelompok II: AV komedonal

didapatkan bahwa kedua data tidak terdistribusi normal maka dipergunakan uji nonparametrik dengan uji Mann-Whitney.

Kadar IL-17 rata-rata pada akne vulgaris tipe papulopustular lebih tinggi apabila dibanding dengan AV tipe komedonal. Pada uji MannWhitney, diketahui bahwa kadar IL-17 serum antara pasien AV tipe papulopustular dan AV tipe komedonal memiliki perbedaan yang tidak bermakna secara statistik ( $p>0,05)$.

\section{Pembahasan}

Pada penelitian ini telah didapatkan hasil kadar IL-17 rata-rata dalam serum pasien AV tipe papulopustular lebih tinggi dibanding dengan AV tipe komedonal. Kadar IL-17 pada penelitian ini tidak menunjukkan perbedaan yang bermakna secara statistik $(p>0,05)$ antara akne vulgaris tipe papulopustular dan komedonal. Inflamasi yang terjadi pada AV terutama diinduksi oleh reaksi imunologis terhadap $P$. acnes ${ }^{3}$ dan bakteri ini dapat meningkatkan respons imun pada kelenjar sebasea. ${ }^{13}$ P. acnes adalah bakteri gram

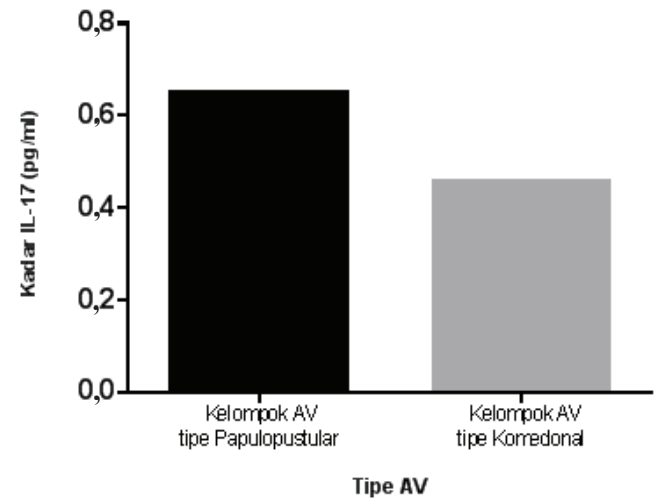

\section{Gambar Perbandingan Kadar IL-17 Serum antara AV Tipe Papulopustular dan Komedonal}

positif anaerob, merupakan bagian dari flora normal kulit ${ }^{4}$ yang berperan penting dalam patogenesis $\mathrm{AV}^{14}{ }^{14}$. acnes dapat mencetuskan respons inflamasi dan juga menginduksi monosit untuk menyekresikan beberapa sitokin proinflamasi seperti IL-17, IL-1 $\beta$, IL-6, TGF- $\beta,{ }^{15}$ IL- $1 \alpha,{ }^{3}$ dan IL-8 ${ }^{16}$ serta TNF- $\alpha .^{3}$ Sitokin-sitokin

Tabel 2 Perbandingan Kadar IL-17 Serum Pasien AV Tipe Papulopustular dengan Komedonal

\begin{tabular}{lccc}
\hline \multicolumn{1}{c}{$\begin{array}{c}\text { Kadar IL-17 } \\
(\mathbf{p g} / \mathbf{m L})\end{array}$} & AV Tipe Papulopustular & AV Tipe Komedonal & Nilai $\mathbf{p}^{*}$ \\
\cline { 2 - 3 } Rata-rata (SD) & $\mathbf{( n = 1 2 )}$ & $\mathbf{( n = 1 2 )}$ & \\
Median & $0,65(1,12)$ & $0,46(0,42)$ & 1,000 \\
Rentang & 0,300 & 0,300 & \\
\hline
\end{tabular}

Keterangan: Kelompok I: AV papulopustular, Kelompok II: AV komedonal 
proinflamasi ini berperan dalam mengawali pembentukan lesi inflamasi $A V^{4,11}$

Pada pasien AV didapatkan peningkatan $P$. acnes secara signifikan dibanding dengan non $\mathrm{AV}$, dan $P$. acnes dapat ditemukan pada papula serta pustula yang merupakan lesi inflamasi dan komedo yang merupakan lesi noninflamasi. ${ }^{17}$ Jumlah bakteri $P$. acnes ditemukan lebih banyak pada lesi inflamasi bila dibanding dengan lesi noninflamasi serta suatu lesi inflamasi dapat menyediakan lingkungan yang lebih sesuai dan nutrisi yang lebih banyak untuk kolonisasi $P$. acnes sehingga dapat meningkatkan proses inflamasi. ${ }^{17}$ Dalam serum pasien AV dengan lesi inflamasi didapatkan peningkatan kadar IL-17 dibanding dengan orang normal. ${ }^{12}$

Pada penelitian ini tidak terdapat perbedaan kadar IL-17 serum antara AV papulopustular dan komedonal. Hasil tersebut menunjukkan bahwa pada AV komedonal kemungkinan sudah terjadi inflamasi. Secara klinis komedo merupakan lesi noninflamasi, namun secara mikroskopis merupakan lesi inflamasi ${ }^{6}$ yang telah dibuktikan dengan ditemukan sitokin proinflamasi IL- $1 \alpha$ pada lesi komedo. ${ }^{7}$ Pada lesi komedo dapat pula ditemukan sitokin lain seperti TNF- $\alpha$ dan sel T $\mathrm{CD}^{+}$dalam jumlah yang banyak. ${ }^{18}$ Sel inflamasi (sel T $\mathrm{CD}^{+}$dan $\mathrm{CD}^{+}$) juga didapatkan meningkat pada lesi mikrokomedo dengan jumlah yang tidak berbeda jauh bila dibanding dengan lesi pustula. $^{6}$

Simpulan, tidak didapatkan perbedaan kadar IL-17 serum antara AV tipe papulopustular dan komedonal, yang menunjukkan bahwa pada lesi komedo kemungkinan sudah terjadi inflamasi.

\section{Daftar Pustaka}

1. Sidiropoulus M. Acne vulgaris: pathogenesis and retinoid therapy. Univ Toronto Med J. 2006;83(2):94-5.

2. Semyonov L. Acne as a public health problem. Italian J Pub Health. 2010;2(7):112-4.

3. KoreckA, Pivarcsi A, Dobozy A, Kemeny L. The role of innate immunity in the pathogenesis of acne. Dermatology. 2003;206(1):96-105.

4. Knor T. The pathogenesis of acne. Acta Dermatovenereol Croat. 2005;13(1):44-9.

5. Tahir M. Pathogenesis of acne vulgaris: simplified. J Pakistan Ass Dermatol. 2010; 20(1):93-7.

6. Jeremy AHT, Holland DB, Roberts SG, Thomson KF, Cunliffe WJ. Inflammatory events are involved in acne lesion initiation. J Invest Dermatol. 1998;107(488):20-7.
7. Sugisaki H, Yamanaka K, Kakeda M, Kitagawa $\mathrm{H}$, Tanaka $\mathrm{K}$, Watanabe $\mathrm{K}$, dkk. Increased interferon-g, interleukin-12p40 and IL-8 production in Propionibacterium acnestreated peripheral blood mononuclear cells from patient with acne vulgaris host response but not bacterial species is the determinant factor of the disease. J Dermatol Sci. 2009;55(1):47-52.

8. Iwakura $Y$, Ishigame $H$, Saijo $S$, Nakae S. Functional specialization of interleukin-17 family members. Immunity. 2011;34(1):14962.

9. Oukka M. Th17 cells in immunity and autoimmunity. Ann Rheum Dis. 2008;67 (Suppl 3):26-9.

10. Ishigame $H$, Kakuta $S$, Nagai T, Kadoki M, Nambu A, Komiyama Y, dkk. Differential roles of interleukin-17A and $17 \mathrm{~F}$ in host defense against mucoepithelial bacterial infection and allergic responses. Immunity. 2009;30(1):108-19.

11. Agak GW, Qin m, Nobe J, Kim MH, Krutzik SR, Tristan GR, dkk. Propionibacterium acnes induces an IL-17 response in acne vulgaris that is regulated by vitamin $A$ and vitamin $D$. J Invest Dermatol. 2014;134(1):366-73.

12. Karadag AS, Ertugrul DT, Bilgili S, Takci Z, Akin KO, Calka O. Immunoregulatory effects of isotretinoin in patients with acne. Br Ass Dermatol. 2012;167(1):433-5.

13. Ochsendorf F. Acne vulgaris. CME Dermatol. 2009;4(1):36-51.

14. Nakatsuji T, Liu YT, Huang CP, Gallo RL, Huang CM. Antibodies elicitated by inactivated Propionibacterium acnes-based vaccines exert protective immunity and attenuate the IL-18 production in human sebocytes: relevance to therapy of acne vulgaris. J Invest Dermatol. 2008;128(10):2451-7.

15. Dessinioti C, Katsambas AD. The role of Propionibacterium acnes in acne pathogenesis:facts and controversies. Clin Dermatol. 2010;28(1):2-7.

16. Kurokawa I, Danby FW, Ju Q, Wang X, Xiang LF, Xia L, dkk. New developments in our understanding of acne pathogenesis and treatment. Exp Dermatol. 2009;18:821-32.

17. Shaheen B, Gonzales M. A microbial aetiology: what is the evidence? $\mathrm{Br} J$ Dermatol. 2011;165(1):474-85.

18. Kubba R, Thappa DM, Sharma R, Vedamurthy M, Dhar S, Criton S, dkk. Acne in India: guidelines for management-IAA consensus document. Indian J Dermatol Venereol. 2009;75(7):5-9. 